\title{
Examining the Livelihood Assets and Sustainable Livelihoods among the Vulnerability Groups in Malaysia
}

\author{
Ahmad Zubir Ibrahim ${ }^{* 1}$, Kalthum Hassan ${ }^{1}$, Roslina Kamaruddin ${ }^{2}$, Abdul Rahim Anuar ${ }^{3}$ \\ 1 School of Government, Universiti Utara Malaysia \\ 2 School of Economics, Finance and Banking, Universiti Utara Malaysia \\ ${ }^{3}$ School of International Studies, Universiti Utara Malaysia
}

\begin{abstract}
Until recently, the livelihood vulnerability group such as paddy farmers, coastal fishers and rubber tappers in rural areas are susceptible to economic shock and climate change such as flood and drought. This situation will jeopardise the livelihoods of this group. In response to that, this study aims to investigate the relationship between livelihood assets and sustainable livelihoods. This study adopts quantitative study with stratified sampling method to select a total of 600 respondents from rural areas in Kedah and Kelantan. The findings confirm that physical asset, natural asset and social asset are significantly related to the achievement of sustainable livelihoods. Some recommendations have been highlighted to assist the concerned parties in improving sustainable livelihoods among the vulnerable group in rural areas.
\end{abstract}

Keywords: Sustainability Livelihood, Livelihoods Vulnerability, Livelihood Asset, Malaysia

JEL Classification: Q56, Q01, N55

Paper Type: Research

\section{INTRODUCTION}

Malaysia has long emphasised the importance of balanced growth to its citizens regardless of their gender, ethnicity, socio-economic status and geographical location. This commitment is reflected in the Tenth and Eleven Five-Year plans. The Tenth Malaysia Plan (2011-2015) was focusing on inclusivity as a critical strategy to achieve prosperous and equitable society, while the Eleventh Five-Year Malaysian Plan (2016-2020) has identified six strategic thrusts with two of the thrusts are focusing on inclusive society and improving well being of all citizen (Economic Planning Unit, 2016). Among the primary

*Corresponding author: E-mail: azubir@uum.edu.my 
focus of the plans is to uplift the B40 group (bottom 40 percent household income group) into middle-class society. To achieve the goal, the Malaysia government has provided access to education, skill-training, physical infrastructures, services and employment opportunities to uplift the socio-economic achievement and well being of all segments of the society particularly the low-income group.

The development achievement is successful especially no uplifting socio-economic adherent of the poor people toward achieving sustainability livelihood. The concept of Sustainable Livelihood (SL) is an attempt to go beyond the conventional definitions and approaches to poverty eradication. The sustainable livelihoods idea was first introduced by the Brundtland Commission on Environment and Development, and the 1992 United Nations Conference on Environment and Development expanded the concept, advocating for the achievement of sustainable livelihoods as a broad goal for poverty eradication (Krantz, 2001).

In 1992, Robert Chambers and Gordon Conway proposed the following composite definition of sustainable rural livelihood that is applied most commonly at the household level:

"A livelihood comprises the capabilities, assets (stores, resources, claims and access) and activities required for a means of living: a livelihood is sustainable which can cope with and recover from stress and shocks, maintain or enhance its capabilities and assets, and provide sustainable livelihood opportunities for the next generation; and which contributes net benefits to other livelihoods at the local and global levels and in the short and long-term."

Curbing vulnerability among households and individuals depends on the available livelihood assets accessed and utilised towards securing livelihoods (Ashley \& Carney, 1999; Krantz, 2001). Accordingly, households and individuals have to struggle to make the livelihood assets available to them to secure their livelihood outcome and to remain resilient against shocks and stress. Notwithstanding the fact that possession of the livelihood assets depends on the efforts of the vulnerable individuals or households, the government has a stake towards access to the livelihood assets and livelihood outcomes which by and large protect those who are not vulnerable, while addressing the problem of the already vulnerable ones. Insecure livelihoods in the today's world made poor livelihood outcomes to be pronounced in the third-World nations (World Bank, 2012) which result into socio-economic crisis, affecting human capabilities and initiatives (Ravallion, 2011).

\section{LITERATURE REVIEW}

Chambers and Conway (1992) stated the Sustainable Livelihoods Framework was used as the basis of this study in which livelihood capital is the core component (Figure 1). The Sustainable Livelihoods Approach (SLA) has been a prominent device used in recent development programs that aimed to reduce poverty and vulnerability in rural households (Neiland, 2004; Stirrat, 2004). SLA is used to report on the relationship between livelihood strategies and livelihood capitals as capital and capabilities framework (Chambers and Conway, 1992; Bebbington, 1999) to reduce poverty and improve livelihoods. SLA is an approach frequently used for development policy and practices, not only as research or conceptual framework employed among academia (Scoones, 1998). 


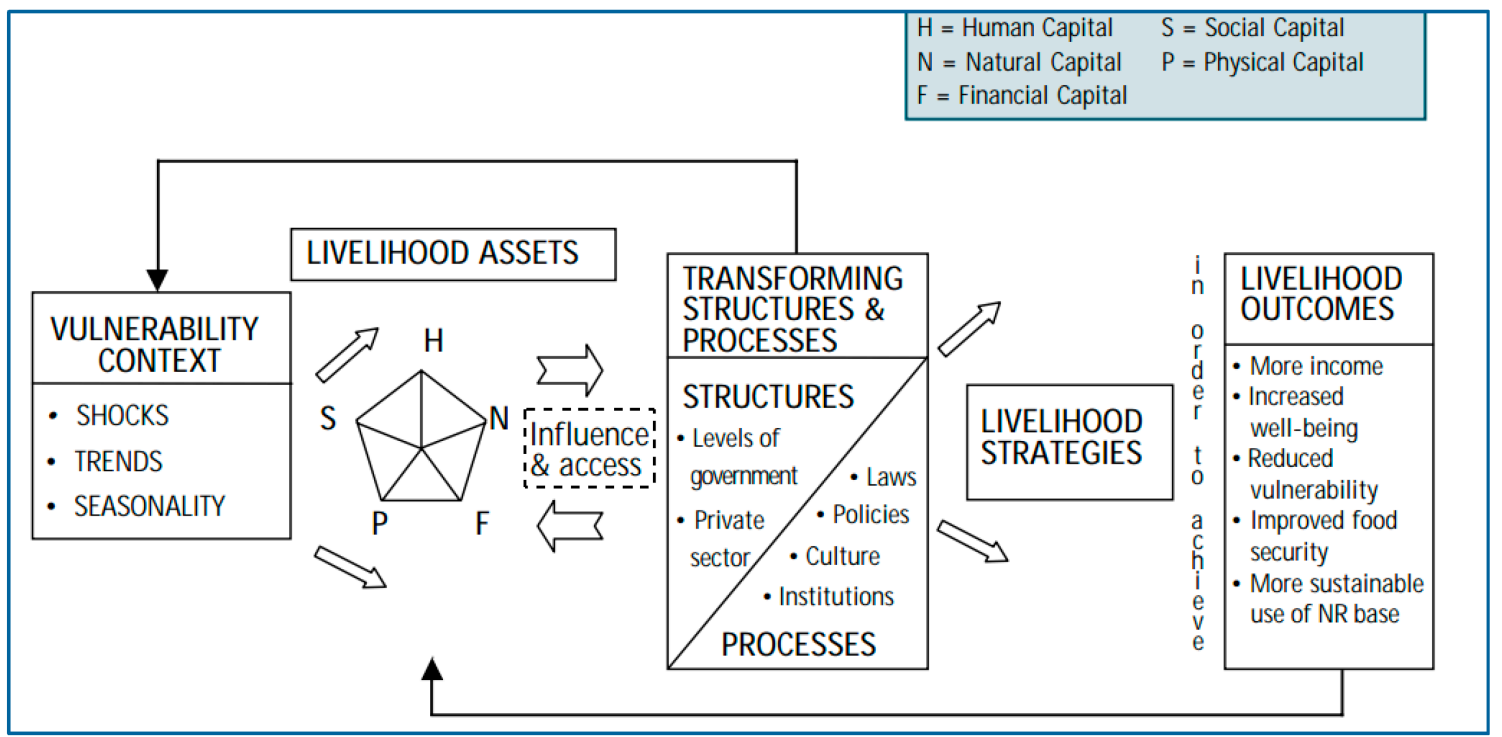

Figure 1. Sustainable Livelihood Framework (DFID 2001)

Livelihood assets is a fundamental condition that affects and reflect the basic livelihoods of farmers with the ultimate goal of alleviating and, finally, eradicating poverty. The livelihoods approach is concerned first and foremost with people. It seeks to gain an accurate and realistic understanding of people's strengths (assets or capital endowments) and how they endeavour to convert strengths into positive livelihood outcomes (Dercon, 2001). The livelihood asset consists of (i) a physical asset; (ii) financial asset (iii) human asset, (iv) social asset and (v) natural asset.

Physical asset means the required accessibilities to facilities needed by households or individuals like transportation, good housing, safe drinking water, and accessibility to medical facilities, market and schools (Samsudin, \& Kamaruddin, 2013). Similarly, physical asset signifies in some specifics fixed like the market, production yard, which are essential in the production of goods and services (Kataria, Curtiss, \& Balmann, 2012). In some other ways it comprises of basic infrastructure like good road to reach market for income generation, decent housing facility, good source of drinking water, and affordable source of energy, and affordable but effective mean communications, and other vital elements of physical asset which contribute towards sustainable livelihood outcomes (Bennett, 2010).

Meanwhile, financial asset includes economic sources that enable vulnerable households and individual to generate income and make an investment which in turn ensure sustainability of livelihood outcomes (Scoones, 1999; DFID, 2001). It composed of stocks of cash in the bank, disposable assets like livestock, and a multitude of income sources such as off-farm labour, government transfers and remittance from relatives which improve livelihoods outcomes (Bajwa, 2015). Therefore financial asset is a collection of the way by which an individual or household make income to sustain livelihoods and invest to acquire more asset and stay away(abstain)from vulnerability related to insecure livelihood outcomes.

While, human asset assumes a combination of capabilities, skills and knowledge, and material health which enable households and individuals to make livelihoods and attain secure livelihood outcome (Krantz, 2001). Human asset entails a combination of abilities that endow the individual or households or individual towards earning livelihoods outcomes (DFID, 2001). Human asset facilitates vulnerable group by improving their 
chances of employment, off-farm engagement, and other forms of engagements which support livelihood outcome and help in combating vulnerability or threat to livelihoods (Weiss, 2015). Put differently, Sen (1997) stressed that human asset relates to individual's capability consisting of knowledge, economic, social and mental ability which together lead to livelihood outcome.

To increase individual's capability, social assets (i.e., social resources) provide prospects to the vulnerable households through social relations and interactions like bonds, bridges and linkage which bring equal mutual benefit to both parties in the social relations (Coleman, 1988). DFID (2001) conceived social asset as the result of social relations among members of a family, peer groups and like minds in the society bound by common interest with an envisaged mutual return. Samsudin and Kamaruddin (2013) stated that social asset involves interactions between households' members or individuals and the social system, social networks, political parties as well local or international based associations. Social asset embodies a sort of trust and reciprocal benefit, mutual interest and cooperate social relation (Coleman, 1988). These conceptions submit that social asset is a social resource that is embedded within the fold of personal relationships of mutual benefits and trust with every actor having an equal stake and opportunity without compromising the interest of the other participant in the interrelations.

Lastly, the natural asset is a collection of natural resources in the physical environment which humans act upon to create livelihoods (Guerry et al., 2015). These natural endowments include river and stream water for fishing and irrigation purposes, land for farming and construction, forest resources, livestock and mineral deposits (Twyman, \& Slayer, 2000). According to Ellis (2000), natural asset symbolises biological and non-biological natural endowments like rivers, lake, land and economic trees, grasses and shrubs that people use to make livelihoods which in turn enhance livelihood outcomes. In general, natural asset depicts natural resources that households and individuals can exploit and utilise for economic purposes to creating livelihoods and in turn helps towards the accomplishment of livelihoods outcomes (Carney, 1998; DFID, 1999; 2001).

To achieved sustainability livelihood, vulnerability is a factor that would threaten the well being the poor. Vulnerability like other concepts does not have a single meaning; it denotes a set of interrelated natural and human-made phenomena that constitute a threat to the livelihoods of households and individuals (Chaudhuri, 2000; Christiaensen \& Subbarao, 2001). Accordingly, McCulloch and Calandrino (2003) conceived vulnerability as the possibility of becoming short of an accepted monetary income which classifies a person as inferior or in poverty. As noted earlier vulnerability is multifaceted signifying that a vulnerable household or individual is facing a series of risks or threats to livelihoods which may be shocks, trends or seasonality. In contrast, vulnerability entails risks, or embody uncertainties of natural occurrences or events that can destroy the socioeconomic well-being of households and individual thereby causing difficulties and consequences related to livelihoods (Christiaensen \& Subbarao, 2001). Therefore, vulnerability may be a product of the risk attributable to nature (Alayande, 2002) or actions by individuals or household (Dercon, 2001).

At the same time, government intervention is critical to address socio-economic problems in the society. It denotes what government intervention towards ensuring relief in the society and therefore has no specific meaning as it has a lot to address (Loewen, 2009). Notwithstanding, Loewen (2009) opines that government intervention means a mechanism government deploys to curb particular socio-economic problems like poverty, crime and unemployment (Loewen, 2009). DFID (1999) stressed government intervention comes in the form of policies and programs employed by the government to solve a particular social problem in society. Likewise, Ibrahim and Alam (2016) conceived government intervention as policy action in term of subsidies in agriculture via the 
provision of improved seeds and fertiliser to improve food production and economic wellbeing of affected farmers. In summary government intervention symbolises support from the government which usually derives in the form of incentives, a subsidy of policy action that aims at improving the well-being of the affected people.

Therefore, based on the findings of the reviewed empirical studies, this study hypothesised as follows:

$\mathrm{H}_{1}$ : There is a significant relationship between physical asset and livelihood outcomes.

$\mathrm{H}_{2}$ : There is a significant relationship between financial asset and livelihood outcomes.

$\mathrm{H}_{3}$ : There is a significant relationship between human asset and livelihood outcomes.

$\mathrm{H}_{4}$ : There is a significant relationship between social asset and livelihood outcomes.

$\mathrm{H}_{5}$ : There is a significant relationship between natural asset and livelihood outcomes.

$\mathrm{H}_{6}$ : There is a significant relationship between government intervention and livelihood outcomes.

$\mathrm{H}_{7}$ : There is a significant relationship between vulnerability and livelihood outcomes.

\section{METHODOLOGY}

The study is based on descriptive quantitative survey design. Data for the study was collected from the vulnerability group through self-designed and self-administered questionnaire covering the various variables identified in the literature. Non-probability convenience sampling technique was adopted. This study is based on primary data collected in 2016 from the study area in Kedah and Kelantan Malaysia, consist paddy farmers, coastal fishers and rubber tappers. In all 600 respondents were used for the study. The questionnaires consist of four parts: Questions concerning demographic information; asset livelihood, vulnerability, coping strategies, and government intervention intention to contribute sustainability livelihood among the vulnerability group. The collected data were processed and analysed by partial least-squares (PLS) path modelling with Smart-PLS 2.0 M3 software (Ringle et al., 2005).

\subsection{Measurement Model}

PLS, based structural equation modelling was adopted for the data analysis. The method is useful for causal-predictive analysis. It does not involve assumptions of homogeneity in variances and covariance of the dependent variable. It also can simultaneously test the structural and the measurement models, providing a complete analysis for the interrelationships. The study used PLS because it makes minimal demands on the data distributions, sample size, and measurement scales and as this study was exploratory (Hair et al., 2014). The Smart PLS Version 2.0 and two-step analysis approach was used to analyse the data. Also, a bootstrapping method was used to determine the significance levels of the loadings, and path coefficients (Gholami, Sulaiman, \& Ramayah, 2013).

This study began with the assessment of the reflective measures using both convergence and discriminant validity in line with Hair et al. (2014). As presented in Table 2 , the measurement models presented the factor loadings, average variance extracted (AVE) and composite reliability (CR) and Cronbach's alpha were used to assess internal consistency reliability and convergence validity (Hair et al., 2016). Most of the loadings for the reflective items exceeded the recommended value of $0.5(0.708)^{2}$. While six indicator items such as AK4 (0.508), AK5 (0.602), F12 (0.345), ASJ (0.573), AS2 (0.415) and AS3 (0.567) recorded loadings below the threshold based on outer loadings relevance test (OLRT). 
CR values (as in Table 2) ranged from 0.75 to 0.82 , which exceeded the recommended value of 0.7 - 0.90 (Hair et al., 2017; Gefen, Straub \& Boudreau, 2000). The AVE was in the range of 0.51 and 0.60 which exceeded the recommended value of 0.5 (Fornell \& Lacker, 1981). Next, the discriminant validity was tested. It was examined by comparing the correlations between constructs and the square root of the AVE for that construct. As shown in Table 3, the square root of the AVE is higher than the correlation with other constructs indicating adequate discriminant validity. Thus the reflective measurement model demonstrated adequate internal consistency reliability, convergent validity and discriminant validity.

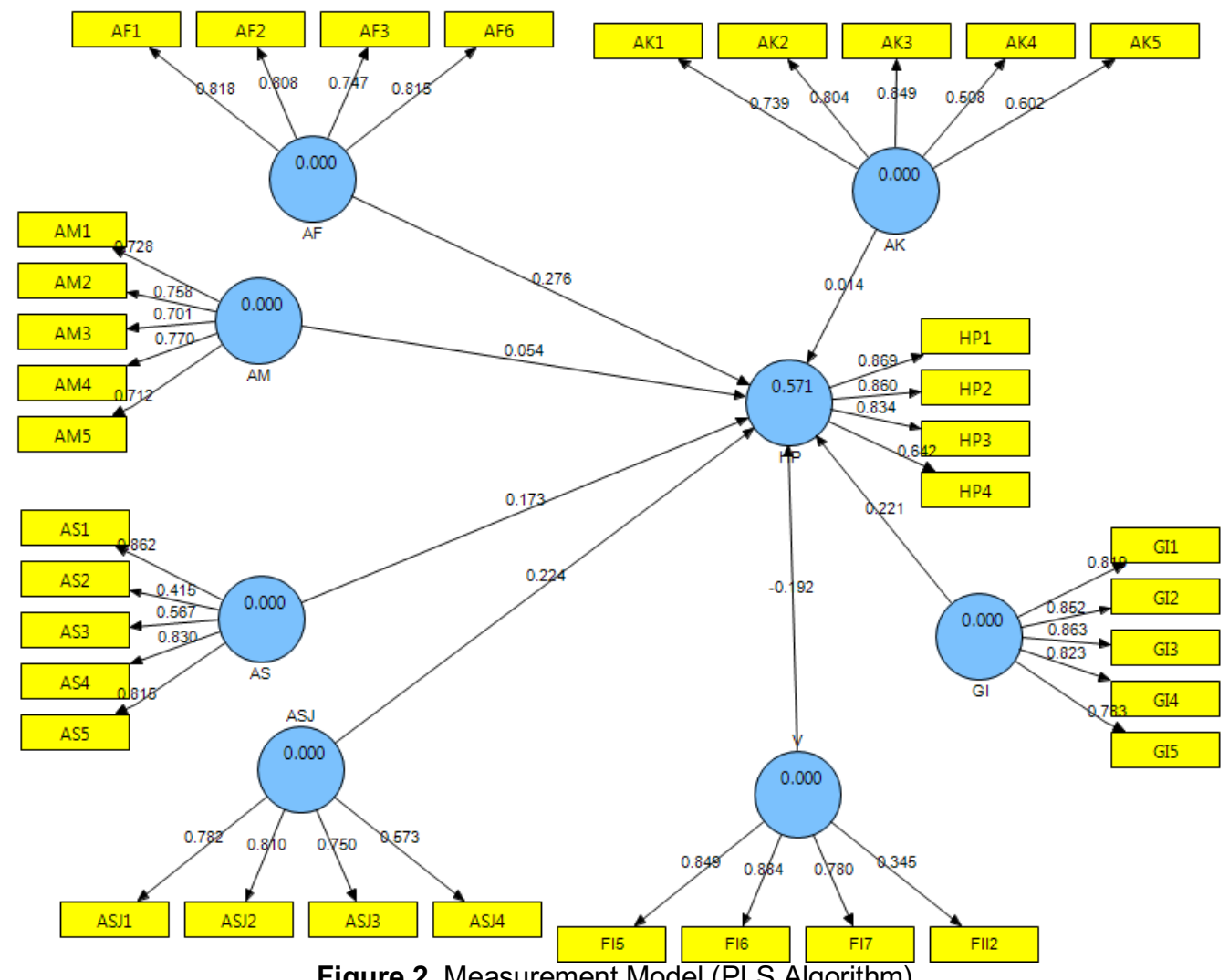

Figure 2. Measurement Model (PLS Algorithm)

Table 1. Reliability and Convergent Validity Assessment Results

\begin{tabular}{|c|c|c|c|c|}
\hline Model Construct & Measurement Item & Loadings & $\begin{array}{l}\text { Average } \\
\text { Variance } \\
\text { Extracted } \\
\text { (AVE) } \\
\end{array}$ & $\begin{array}{l}\text { Composite } \\
\text { Reliability } \\
\text { (CR) }\end{array}$ \\
\hline Physical Asset & $\begin{array}{l}\text { AF1- Transportation } \\
\text { AF2- Distance to town } \\
\text { AF3- Clean water supply } \\
\text { AF6- Electricity supply }\end{array}$ & $\begin{array}{l}0.82 \\
0.81 \\
0.75 \\
0.81\end{array}$ & 0.63 & 0.87 \\
\hline Finance asset & $\begin{array}{l}\text { AK1- Saving } \\
\text { AK2- Income } \\
\text { AK3- Part-time income } \\
\text { AK4- Subsidies }\end{array}$ & $\begin{array}{l}0.74 \\
0.80 \\
0.85 \\
0.51\end{array}$ & 0.51 & 0.83 \\
\hline Human Asset & $\begin{array}{l}\text { AM1-Education } \\
\text { AM2- Skill } \\
\text { AM3- Age } \\
\text { AM4- Knowledge } \\
\text { AM5- Health }\end{array}$ & $\begin{array}{l}0.73 \\
0.76 \\
0.70 \\
0.77 \\
0.71\end{array}$ & 0.54 & 0.85 \\
\hline
\end{tabular}




\begin{tabular}{|c|c|c|c|c|}
\hline \multirow[t]{5}{*}{ Social Asset } & AS1-Involve in society & 0.86 & 0.52 & 0.83 \\
\hline & $\begin{array}{l}\text { AS2-Involve in a Non-government } \\
\text { organization }\end{array}$ & 0.42 & & \\
\hline & AS3-Involve in community engagement & 0.57 & & \\
\hline & AS4- Relationship in community & 0.83 & & \\
\hline & AS5- Position in community/organization & 0.81 & & \\
\hline \multirow[t]{4}{*}{ Natural Asset } & ASJ1-Acess food from environment & 0.78 & 0.54 & 0.82 \\
\hline & ASJ2-Impact climate change & 0.81 & & \\
\hline & ASJ3- Pollution problem & 0.75 & & \\
\hline & ASJ4-Disease threats to production & 0.57 & & \\
\hline Government & GI1 - Health facilities & 0.82 & 0.67 & 0.91 \\
\hline \multirow[t]{3}{*}{ Intervention } & GI2- Economic development by government & 0.85 & & \\
\hline & GI3 -Public participation & 0.86 & & \\
\hline & G14- Subsides delivery & 0.82 & & \\
\hline \multirow[t]{4}{*}{ Vulnerability } & FI5-Food supply is broken & 0.87 & 0.56 & 0.82 \\
\hline & Fl6-Cost of living increase & 0.86 & & \\
\hline & FI7- Job loss & 0.83 & & \\
\hline & FII2- Food insecurity & 0.64 & & \\
\hline Livelihood & HP1- Food security & 0.87 & 0.65 & 0.88 \\
\hline \multirow[t]{3}{*}{ Outcomes } & HP2- Well being & 0.86 & & \\
\hline & HP3-Getting perfect education & 0.83 & & \\
\hline & HP4-Food supply in market & 0.64 & & \\
\hline
\end{tabular}

Table 1 shows the convergent validity, and discriminant validity of the constructs of the study and all the constructs have met the requirements as per individual item reliability, AVE and Composite reliability.

Table 2 shows the discriminant validity of the latent construct of this study, which indicates the level of variance between and amongst the constructs of the study as suggested (Duarte \& Roposo, 2010).

Table 2. Discriminant Validity of Constructs

\begin{tabular}{lllllllll}
\hline Constructs & PA & FA & HA & SA & NA & GI & LO & Vuln. \\
\hline Physical asset & $\mathbf{0 . 7 9}$ & & & & & & & \\
Financial asset & 0.47 & $\mathbf{0 . 7 1}$ & & & & & & \\
Human asset & 0.44 & 0.36 & $\mathbf{0 . 7 3}$ & & & & & \\
Social asset & 0.53 & 0.34 & 0.53 & $\mathbf{0 . 7 2}$ & & & & \\
Natural asset & 0.48 & 0.44 & 0.51 & 0.45 & $\mathbf{0 . 7 3}$ & & & \\
Govt. Intervention & 0.28 & 0.21 & 0.37 & 0.31 & 0.25 & $\mathbf{0 . 8 2}$ & & $\mathbf{0 . 7 5}$ \\
Livelihood outcomes & 0.61 & 0.41 & 0.52 & 0.52 & 0.55 & 0.45 & $\mathbf{0 . 8 1}$ \\
Vulnerability & -0.19 & -0.21 & -0.27 & 0.02 & -0.12 & -0.08 & -0.31 & \\
\hline
\end{tabular}

\subsection{Assessment of Structural Model}

After the assessment of the measurement model, this study also evaluated the structural model which usually deals with the assessment of the predictive correlation between the exogenous constructs and endogenous construct (Henseler \& Sarstedt, 2013).

\subsection{Path Coefficients Estimates}

This study evaluated the hypothesised relationships of the study using path coefficients through the examination of the beta value, standard error and $t$-value as suggested (Hair et al., 2014).

Table 3. Hypothesis Testing Result 


\begin{tabular}{lllll}
\hline Path Relationship and Direction & Beta & $\begin{array}{l}\text { Std. } \\
\text { Error }\end{array}$ & $\begin{array}{l}\text { T } \\
\text { Statistics }\end{array}$ & Results \\
\hline Physical asset $\rightarrow$ Livelihood outcome & 0.276 & 0.092 & $2.981^{* * *}$ & Significance \\
Financial asset $\rightarrow$ Livelihood outcome & 0.014 & 0.080 & 0.178 & Non Significance \\
Human asset $\rightarrow$ Livelihood outcome & 0.054 & 0.097 & 0.553 & Non Significance \\
Social asset $\rightarrow$ Livelihood outcome & 0.172 & 0.088 & $1.961^{* *}$ & Significance \\
Natural asset $\rightarrow$ Livelihood outcome & 0.223 & 0.091 & $2.440^{* * *}$ & Significance \\
Government Intervention $\rightarrow$ Livelihood outcome & 0.220 & 0.081 & $2.697^{* * *}$ & Significance \\
Vulnerability $\rightarrow$ Livelihood outcome & -0.191 & 0.075 & $2.548^{\star * *}$ & Significance \\
\hline
\end{tabular}

Note: $\left({ }^{* * *}\right)$ significant at $1 \%,\left({ }^{* *}\right)$ significant at $5 \%$, and value without asterisk stand for non-significant.

Table 3 shows the results of testing the structural model. These show that (physical asset $\beta=0.276, T$ value $=2.981$; social asset $\beta=0.172, T$ value $=1.961$; natural asset $\beta=$ 0.223 , T value $=2.440$; government intervention $\beta=0.220$, T value $=2.697$; Vulnerability $\beta=-0.191$, $T$ value $=2.548$ ) which means that $\mathrm{H}_{1}, \mathrm{H}_{4}, \mathrm{H}_{5}, \mathrm{H}_{6}, \mathrm{H}_{7}$ are supported, however only $\mathrm{H}_{1}, \mathrm{H}_{4}, \mathrm{H}_{5}, \mathrm{H}_{6}$ are positively related to livelihood outcome, while $\mathrm{H}_{7}$ is negatively related to livelihood outcomes because the Beta value has a negative sign (see Hair et al., 2014). Furthermore, financial asset $(\beta=0.014$, $\mathrm{T}$ value $=0.178)$; human asset $(\beta=$ 0.054 , $T$ value $=0.553$ ) were found to be non- significant (see Hair et al., 2014) signifying that the hypothesized relationships $\left(\mathrm{H}_{2}\right.$ and $\left.\mathrm{H}_{3}\right)$ were not supported.

\section{DISCUSSION}

The finding of this study showed that $\mathrm{H}_{1}$ is supported, that is, signifying the positive relationship between physical asset and livelihood outcomes. This finding conforms with the findings of Kamaruddin and Baharuddin ( 2015), Lim and Mansur (2015), and Kasim et al., (2017) which all advocated that access to physical asset enhance income and wellbeing of households and individuals as such it has impacts on the livelihood outcomes. Therefore, this study submits that physical asset correlate positively and significantly with livelihood outcomes. The finding of this study showed that $\mathrm{H}_{2}$ is not supported signifying that there is no relationship between financial asset and livelihood outcome. The result of this study contravenes the finding of previous studies (Lim, \& Mansur, 2015; Unmesh, \& Narayanan, 2015; Shehu, \& Abubakar, 2015; Kamaruddin, \& Samsudin, 2014; Kasim et al., 2017) which asserted that financial asset influences livelihood outcomes.

The results of this study indicated that $\mathrm{H}_{3}$ is not supported referring that there is no relationship between human asset and livelihood outcomes which is contrary to the findings of previous empirical studies (Chen et al., 2013; Samsudin, \& Kamaruddin, 2013; Kasim et al., 2017). In essence, the result depicts that human asset has no impact on livelihood outcome. In relation to hypothesis $\mathrm{H}_{4}$, results of this study indicated that there is a relationship between social asset and livelihood outcomes as the path analysis suggested that the hypothesis is supported positively. The finding is not surprising as previous empirical studies opined that there is a correlation between social asset and livelihood outcomes (Oumer \& De Neergaard, 2011; Alfonso et al., 2015; Islam, \& Yew, 2013; Thi et al., 2013).

Similarly, hypothesis $\mathrm{H}_{5}$ of this study is supported and consistent with past empirical studies, which stressed that natural asset improves the livelihoods outcomes and livelihood security (Lim, \& Mansur, 2015; Kamaruddin, \& Samsuddin, 2014; Adunga, 2013; Oumer \& De Neergard, 2011; Van der Berg, 2010; Ansoms, 2010). The finding did not come as a surprise as past studies supported that, therefore these studies confirm that natural asset is critical to livelihood outcomes as such positive relationship subsists. More so, $\mathrm{H}_{6}$ which presumed a relationship between government intervention and livelihood outcomes was found to be supported by the empirical data of this study. The result concurs with the studies of (Lim \& Mansur, 2015; Ibrahim, \& Alam 2016; Kasim et al., 2017). 
Accordingly, the finding of the present study confirmed that there is a positive relationship between government intervention and livelihood outcomes. In a nutshell, the result depicts that support from government affects livelihood outcomes of households and individuals. Consequently, the study's finding from the empirical data and path analysis revealed that there is a correlation between vulnerability and livelihood outcomes. This supports the hypothesis 7 of this study however the relationship was found to be a negative relationship which means that vulnerability affects livelihood outcomes of vulnerable households and individuals negatively. The finding of this study is in line with the findings of studies (Kapoi \& Charles, 2015; Atedhor, 2015; Lim \& Mansur, 2015) who submitted that vulnerability threaten livelihood outcomes as the affected households and individual stand the risk of compromised livelihoods. Therefore it is not surprising that this study unveils negative relationship between vulnerability and livelihood outcomes. In essence, shocks, trends and seasonality hurt the livelihoods of the vulnerable groups.

\section{CONCLUSION AND RECOMMENDATION}

The empirical data of this study analyzed using PLS-SEM through path analysis revealed that livelihood outcome is influenced by a number of factors (livelihood assets, government intervention, and vulnerability) as out of the seven (7) hypotheses formulated five (5) were found to be correlated with livelihood outcomes $\left(\mathrm{H}_{1}, \mathrm{H}_{4}, \mathrm{H}_{5}, \mathrm{H}_{6}, \& \mathrm{H}_{7}\right)$ and therefore are supported although $\mathrm{H}_{7}$ showed negative relationship, notwithstanding the hypothesized relationships are valid, while two (2) other hypotheses were not supported $\left(\mathrm{H}_{2} \& \mathrm{H}_{3}\right)$ depicting that they do not affect or have impact on livelihood outcomes.

Consequently, this study submits that physical asset, social asset, natural asset, government intervention and vulnerability are related to livelihood outcomes, while financial asset and human asset do not have relation with livelihood outcomes.

However, due to increase sustainability livelihood among the poor groups in Malaysia, accessibility to quality education and skills training among students from B40 households should be enhanced. Institutions of higher learning and skills training institutes should be encouraged to provide more places for these students through special entry qualification criteria and enrolment quota. This will be complemented with the provision of financial aid. B40 households in rural areas who are self-employed such as farmers, fishers and smallholders, will be encouraged to adopt modern technology to increase productivity and income. Structured modular programs focusing on modern farming techniques and good agricultural practices will be intensified. Amalgamation of land and merging of small-scale business activities will also be encouraged to gain the benefit of economies of scale. This study affirms the need by relevant agencies such as Federal Agriculture Marketing Authority (FAMA), Malaysian Agricultural Research and Development Institute (MARDI) and Fisheries Development Authority of Malaysia (LKIM) to provide relevant services and facilitation to these households.

\section{ACKNOWLEDGEMENTS}

Funding for this project comes from the Ministry of Higher Education (MOHE) Research Grant FRGS Code SO 13249.

\section{REFERENCES}

Adunga, E. (2013). Factors influencing income level of agro-pastoral communities. International Journal of Social Economics, 40(3), 207-219. 
Ahmed, N., Troel, M., Allison, E. H., \& Muir, J. F. (2010). Prawn postlarvae fishing in coastal Bangladesh: Challenges for sustainable livelihood. Marine Policy, 34(2), 218-227

Akudugu, M. A. (2011). Rural banks, financial capital and livelihoods development of women farmers in Ghana. Journal of Enterprising Communities: People and Places in the Global Economy, 5(4), 248-264. http://doi.org/10.1108/17506201111177307

Alayande, B.A. (2002). Determinants of vulnerability to Poverty, a World Bank Commissioned Study.

Alfonso, C., Mendoza, S., Czerny, M., Allec, A., Pineda, L., Alonso, O., \& Rojas, V. (2015). Miscellanea geographica. Regional studies on development livelihood assessment in district 1 of Medellin-Colombia, 19(4), 9-20. http://doi.org/10.1515/mgrsd-2015-0025.

Ansoms, A. (2008). Rural poverty and livelihoods profiles in post-genocide Rwanda. Discussion paper. Institute of Development Policy and Management. University of Antwerp.

Ashley, C., \& Carney, D. (1999). Sustainable livelihoods: Lessons from early experience. London, UK: Russell Press Ltd.

Atedhor, G. O. (2015). Agricultural vulnerability to climate change in Sokoto State, Nigeria. African Journal of Food, Agriculture, Nutrition and Development, 15(2), 9856-9871.

Bajwa, S. K. (2015). A study of the status of livelihood assets at household Level: Evidence from Saidpur Village. Pakistan Institute for Development Economics. Discussion paper 3.

Bennett, N. (2010). Sustainable livelihoods from theory to conservation practice: An extended annotated bibliography for prospective application of livelihoods approaches in protected area community research.

Carney, D. (1998). Implementing the sustainable rural livelihoods: What contribution can we make? Department of International Development, UK.

Chaudhuri, S. (2000). "Empirical methods for Assessing household vulnerability to poverty", Mimeo Department of Economics and School of International and Public Affairs. Columbia University.

Chen, H., Zhu, T., Krott, M., Calvo, J. F., Ganesh, S. P., Makoto, I. (2013). Measurement and evaluation of livelihood assets in sustainable forest common governance. Land Use Policy, 30, 908-914.

Christiaensen, L., \& Subbarao, K. (2001). Towards an understanding of vulnerability in rural Kenya. Mimeo. The World Bank. Washington, D.C.

Coleman, J. S. (1988). Social capital in the creation of human capital. American Journal of Sociology, 9, 95-120. http://doi.org/10.1086/228943.

Department for International Development. (1999). Sustainable livelihoods guidance sheets. London: DFID.

Department for International Development. (2001). Sustainable livelihoods guidance sheets. www.livelihoods.org/info/info_guidanceSheets.html\#6: DFID.

Dercon, S. (2001). Assessing Vulnerability to Poverty. Mimeo, Centre for the Study of African Economies, University of Oxford.

Duarte, P. A. O., \& Raposo, M. L. B. (2010). "A PLS model to study brand preference: An application to the mobile phone market". In V. Esposito Vinzi, W. W. Chin, J. Henseler \& H. Wang (Eds.), Handbook of Partial Least Squares (pp. 449-485). Springer Berlin Heidelberg.

Ellis, F. (2000). The determinants of rural livelihood diversification in developing countries. Journal of Agricultural Economics, 51, 289-302.

Fornell, C., \& Larcker, D. F. (1981). Evaluating structural equation models with unobservable variables and measurement error. Journal of Marketing Research, 18(1), 39-50.

Gholami, R., Sulaiman, A. B., Ramayah, T., \& Molla, A. (2013). Senior managers' perception of green information system (IS) adoption and environmental performance: Results from a field survey. Information \& Management, 50, 431-438.

Gefen, D., Straub, D., \& Boudreau, M. C. (2000). Structural equation modelling and regression: Guidelines for research practice. Communications of the Association for Information Systems, 4(1), 7.

Guerry, A. D., Polasky, S., Lubchenco, J., Chaplin-Kramer, R., Daily, G. C., Griffin, R., Vira, B. (2015). Natural capital and ecosystem services informing decisions: From promise to practice. In Proceedings of the National academy of Sciences, 112, 7348-7355. http://doi.org/10.1073/pnas.1503751112. 
Hair Jr, J. F., Hult, G. T. M., Ringle, C., \& Sarstedt, M. (2016). A primer on partial least squares structural equation modelling (PLS-SEM): Sage Publications.

Hair, F. J., Joe, Sarstedt, M., Hopkins, L., \& Kuppelwieser, G. V. (2014). Partial least squares structural equation modelling (PLS-SEM). An emerging tool in business research. European Business Review, 26(2), 106-121.

Henseler, J., \& Sarstedt, M. (2013). Goodness-of-fit indices for partial least squares path modelling. Computational Statistics, 1-16.

Ibrahim, A. Z., \& Alam, M. M. (2016). Climatic changes, government interventions, and paddy production: an empirical study of the Muda irrigation area in Malaysia. International Journal of Agricultural Resources, Governance and Ecology, 12(3), 292-304.

Islam, G. M. N., \& Yew, T. S. (2013). Property rights and access: The case of community-based fisheries management in Bangladesh. Journal of Agricultural Science, 5(6). http://doi.org/10.5539/jas.v5n6p164.

Kamaruddin, R., \& Baharuddin, A. (2015). The importance of good aquaculture in improving fish farmers' income: A case of Malaysia. International Journal of Social Economics, 42(12), 10901105. http://doi.org/10.1108/IJSE-02-2014-0028

Kamaruddin, R., \& Samsudin, S. (2014). The sustainable livelihoods index: A tool to assess the ability and preparedness of the rural poor in receiving entrepreneurial project. Journal of Social Economics Research, 1(6), 108-117.

Kapoi, K. J., \& Charles, N. M. (2014). Livelihood vulnerability assessment in the context of drought hazard: A case study of Baringo county, Kenya. International Journal of Science and Research, 3(3),346-349.

Kasim, Y., Ibrahim, A. Z., \& Din, B. B. H. (2017). Understanding the effect of access to livelihood assets and government intervention on poverty reduction: A partial least squares approach. International Journal of Emerging Trends in Engineering and Development, 7(4), 139-154.

Kataria, K., Curtiss, J., \& Balmann, A. (2012). Drivers of agricultural physical capital development: Theoretical Framework and Hypotheses (No. 122). Centre for European Policy Studies.

Krantz, L. (2001). The sustainable livelihood approach to poverty reduction, SIDA. Division for policy and socio-economic analysis. Retrieved fromhttp://www.forestry.umn.edu/prod/groups/cfans/@pub/@cfans/@forestry/documents/asset/cf ans_asset_202603.pdf

Kumo, K. (2015). Research on Poverty in Transition Economies: A Meta-analysis on Changes in the Determinants of Poverty (No. 51). Russian Research Center, Institute of Economic Research, Hitotsubashi University.

Lim. G. N., \& Mansur, K. (2015). Understanding poverty and vulnerability by utilizing the sustainable livelihood approach: A comprehensive study of rungus ethnic in Sabah, Malaysia. Malaysian Journal of Business and Economics, 2(1), 1-24.

Loewen, G. (2009). A compendium of poverty reduction strategies and framework. Canada, Tamarack. www.tamarackcommunity.ca.

McCulloch, J. and C. Calandrino (2003). Poverty and vulnerability. American Economic Review Papers and Proceedings, 84 (2): 221-225.

Méndez-Lemus, Y., \& Vieyra, A. (2014). Tracing Processes in Poverty Dynamics: A Tale of Periurban Small-scale Farmers in Mexico City. Urban Studies, 51(10), 2009-2035.

Ng'ang'a, S. K., Jeannette, V., Notenbaert, A., Moyo, S., \& Herrero, M. (2011). Household livelihood strategies and livestock benefits dependence in Gaza province of Mozambique. African Journal of Agricultural Research, 6(3), 560-572. http://doi.org/10.5897/AJAR10.399.

Olugbire, O. O., Falusi, A. O., Adeoti, A. I., Oyekale, A. S., \& Adeniran, O. A. (2011). Non-farm income diversification and poverty reduction in Nigeria: A propensity-score matching Analysis. Continental Journal of Agricultural Science, 5(3), 21-28.

Oumer, A. M., \& de Neergaard, A. (2011). Understanding livelihood strategy-poverty links: empirical evidence from central highlands of Ethiopia. Environment, Development and Sustainability, 13(3), 547-564.

Ravallion, M. (2011). On multidimensional indices of poverty. Journal of Economic Inequality, 9(2), 234-248.

Ringle, C., Wende, S., \& Will, A. (2005). Smart-PLS Version 2.0 M3. University of Hamburg. 
Samsudin, S., \& Kamaruddin, R. (2013). Distribution of the livelihood asset among the hardcore poor: Evidence from Kedah, Malaysia. World Applied Science Journal, 28, 38-42. DOI: 10.5829/idosi.wasj.2013.28.efmo.27008

Scoones, I. (1998). "Sustainable rural livelihoods: A framework for analysis". IDS Working Paper 72, IDS, Brighton, UK.

Sen, A. (1997). Human capital and human capability. World Development, 25(12), 1959-1961.

Seng, K. (2015). The effects of non-farm activities on farm households' food consumption in rural Cambodia. Development Studies Research, 2(1), 77-89 DOI: 10.1080/21665095.2015.1098554.

Shehu, A \& Abubakar, N. (2015). Determinants of participation of farm households in nonenterprise activities in Nigeria. International Journal of Economics, Commerce and Management. III (6), 57-71.

Su. F, \& Shang, H.Y. (2012). Relationship analysis between livelihood assets and livelihood strategies: A Heihe River Basin example, Sciences in Cold and Arid Regions, 4(3): 0265-0274

Thi, H., Dao, T., \& Manh, P. H. (2013). Settlement of household livelihoods for poor fishers: The case of Cam Ranh reservoir, Khanh Hoa Province. Asian Journal of Poverty, 1(1), 1-7.

Twyman, C., \& Slater, R. (2005). Hidden livelihoods? Natural resource-dependent livelihoods and urban development policy. Progress in Development Studies, 5(1), 1-15.

Unmesh, P., \& Narayanan, K. (2015). How effective are coping mechanisms in securing livelihoods against climatic aberrations? International Journal of Climate Change Strategies and Management, 7(3), 359-374. http://doi.org/10.1108/IJCCSM-07-2014-0085.

Weiss, Y. (2015). Gary Becker on human capital. Journal of Demographic Economics, 81(01), 2731. http://doi.org/10.1017/dem.2014.4.

World Bank (2012). An update to the World Bank's estimate of consumption in the Developing World. Washington, DC: World Bank. 